\title{
PLASMA HOMOCYSTEINE CONCENTRATIONS IN PATIENTS WITH RHEUMATOID ARTHRITIS
}

\section{Dragan Vasiljevic ${ }^{1}$, Aleksandra Tomic-Lucic ${ }^{2}$, Sandra Zivanovic ${ }^{3}$, Mirjana Milosavljevic ${ }^{1}$,}

Snezana Radovanovic ${ }^{4}$, Nebojsa Andjelkovic ${ }^{5}$, Dragan Djuric ${ }^{6}$ and Mirjana Veselinovic ${ }^{2}$

${ }^{1}$ Department of Hygiene, Faculty of Medical Sciences, University of Kragujevac and Institute for Public Health, Kragujevac, Serbia ${ }^{2}$ Department of Social Medicine, Faculty of Medical Sciences, University of Kragujevac and Institute for Public Health, Kragujevac, Serbia ${ }^{3}$ Faculty of Hotel Management and Tourism, Vrnjačka Banja, Serbia ${ }^{4}$ Department of Rheumathology, Clinical Center "Kragujevac", Serbia ${ }^{5}$ Clinic of Hematology, Clinical Center "Kragujevac", Serbia

${ }^{6}$ Institute of Medical Physiology "Richard Burian”, Faculty of Medicine, Belgrade, Serbia

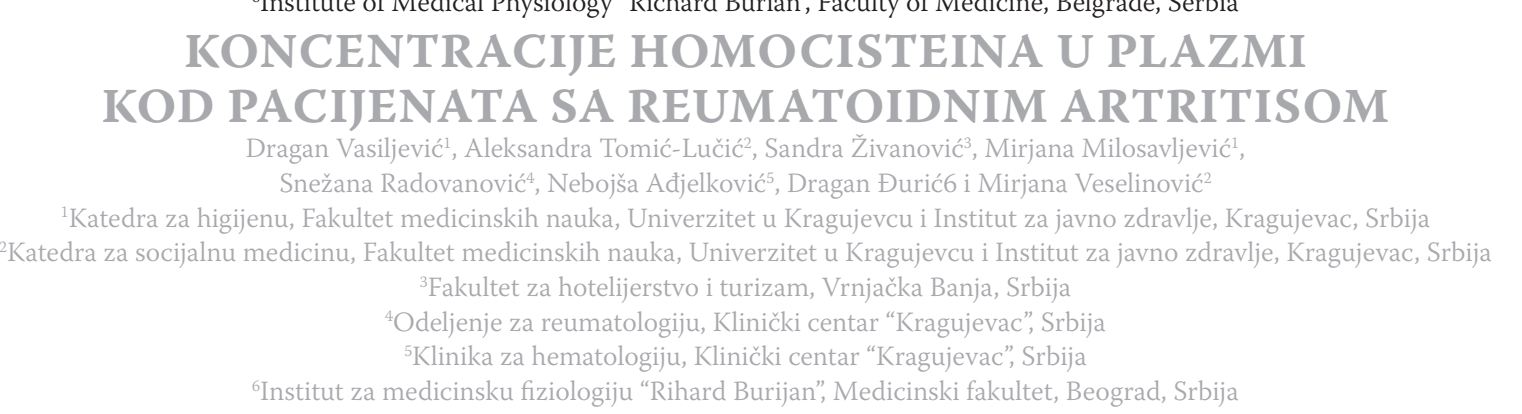

\begin{abstract}
In this study, we investigated the concentration of serum homocysteine (Hcy) in patients with rheumatoid arthritis (RA) compared with the control group and the connection between homocysteine and parameters of inflammation and disease activity. Sixty RA patients and 20 healthy controls were included in the study, and clinical examination and investigation were performed during which disease activity was assessed. Peripheral blood samples were used for all of the assays. Levels of Hcy were $33 \%$ higher in the RA patients than in the control subjects (mean $+/-S D 11.79 \pm 3.72 \mu \mathrm{mol} / \mathrm{L}$ versus $8.90 \pm 1.38 \mu \mathrm{mol} / \mathrm{L} ; p<0.01)$. A significant correlation was found between parameters of inflammation (C-reactive protein) and homocysteine in patients ( $r=0.322, p=0.012)$. Patients with high disease activity had a significantly greater increase in homocysteine $(p<0.05)$. An increase in plasma homocysteine in RA patients is related to the parameters of inflammation and disease activity. Elevated Hcy levels occur commonly in patients with $R A$ and may explain some of the increased cardiovascular mortality seen in RA patients.
\end{abstract}

Keywords: homocysteine, rheumatoid arthritis, disease activity

\section{SAŽETAK}

U ovoj studiji, istraživali smo serumske koncentracije homocisteina (Hcy) kod pacijenata koji boluju od reumatoidnog artritisa (RA) u poredenju sa kontrolnom grupom, kao i povezanost izmedu homocisteina sa parametrima inflamacije i stanjem bolesti. U studiju je ukliučeno 60 pacijenata sa RA i 20 zdravih osoba koji su podvrgnuti kliničkom israživanju i ispitivanju na osnovu čega je izvršena procena stanja bolesti. Za sve analize korišćeni su uzorci periferne krvi. Nivoi homocisteina kod pacijenata sa RA bili su 33\% viši u odnosu na ispitanike u kontrolnoj grupi (mean + - SD 11.79 $\pm 3.72 \mu \mathrm{mol} / \mathrm{L}$ versus $8.90 \pm 1.38 \mu \mathrm{mol} / \mathrm{L} ; p<0.01)$. Utvrdena je značajna korelacija između parametara zapaljenja (C-reaktivni protein) $i$ homocisteina kod pacijenata $(r=0.322$, $p=0.012$ ). Pacijenti sa bolešću u visokom stanju aktivnosti su imali značajnije povećanje koncentracije homocisteina $(p<0.05)$. Povećanje homocisteina u plazmi kod pacijenata sa RA je u vezi sa parametrima zapaljenja i stanjem bolesti. Povišeni nivoi Hcy obično su prisutni kod pacijenata sa RA, i mogu objasniti povećanje smrtnosti usled prisustva kardiovaskularnih oboljenja koja se sreću kod ovih pacijenata.

Ključne reči: homocistein, reumatoidni artritis, stanje bolesti

\section{(n)}

\section{ABBREVIATIONS}

anti-CCP - antibodies against cyclic citrullinated peptide CIRD - chronic inflammatory rheumatic diseases COX-2 - cyclooxygenase 2

CRP - C-reactive protein CVD - cardiovascular disease

DAS - disease activity score

DMARD - disease-modifying antirheumatic drugs

ELISA - enzyme-linked immune sorbent assay

ESR - erythrocyte sedimentation rate

HAQ - Health Assessment Questionnaire

Hcy - homocysteine

MTHR - methylene-tetrahydrofolate reductase

NSAID - nonsteroidal anti-inflammatory drug

RA - rheumatoid arthritis

RF - rheumatoid factor

VAS - visual analogue score 


\section{INTRODUCTION}

The risk of cardiovascular morbidity and mortality is increased in rheumatoid arthritis (RA) (1). The classical cardiovascular risk factors, including smoking, hypertension, dyslipidaemia, insulin resistance and diabetes mellitus, obesity and physical inactivity, do not explain the excess cardiovascular risk observed in people with rheumatoid arthritis, although they do contribute, albeit in a different way or to a lesser extent, to rheumatoid arthritis (2). A very important link between rheumatoid arthritis and cardiovascular disease is inflammation because it plays a key role in all stages of atherosclerosis from endothelial dysfunction to plaque rupture and thrombosis. Inflammation also has an influence on and exacerbates some traditional cardiovascular risk factors. To date, the exact pathophysiologic mechanism underlying the relationship between cardiovascular disease and rheumatoid arthritis is unclear (2). Clinical research has proven that rheumatoid arthritis (RA) patients have a higher prevalence of classical risk factors than the general population. Recently, there has been an emphasis on new risk factors that can contribute to cardiovascular disease (CVD) (3).

Homocysteine (Hcy) is a sulfur amino acid which metabolism exists at the intersection of two pathways: remethylation, which requires folic acid and vitamin B12 coenzymes, and trans-sulfuration, which requires pyridoxal-5'-phosphate, the vitamin B6 coenzyme (4). Prospectively, elevated plasma Hcy is associated with increased total and cardiovascular mortality, increased incidence of stroke, increased incidence of dementia and Alzheimer's disease, increased incidence of bone fracture, and higher prevalence of chronic heart failure (4). However, Hcy is not included in current guidelines for the diagnosis of subclinical disease in high-risk asymptomatic individuals. Mean Hcy levels were consistently found to be higher in men compared with women (5).

The correlation between the plasma homocysteine levels and commonly used inflammatory markers (C-reactive protein and erythrocyte sedimentation rate) in patients with RA is unclear. To date, it has been shown that multiple rheumatic diseases including RA, scleroderma, ankylosing spondylitis, systemic lupus erythematosus and gout may be associated with hyperhomocysteinemia, which may, in turn, be associated with cardiovascular events (6-9). In many studies that examined serum Hcy levels in rheumatic disease, serum Hcy levels were higher in the case group than the control group (6-11).

In this study, we compared the concentration of plasma Hcy among patients with RA and healthy participants belonging to control group. We also examined the correlation between disease activity and inflammatory markers in RA patients.

\section{PATIENTS AND METHODS}

\section{Study population}

Sixty patients with RA (mean age 52.46 years, $\mathrm{SD} \pm 7.39$, min 37-max 60 years) who fulfilled the 2010 American College of Rheumatology criteria for RA were enrolled in this study (12). Patients were recruited from the outpatient unit of the rheumatology department at the Clinical Center Kragujevac, Serbia, in 2014. The median duration of illness was 7 years (range 2-11 years). The erythrocyte sedimentation rate (ESR) was determined using the Westergreen technique, and C-reactive protein (CRP) was measured using nephelometry. Serum rheumatoid factor (RF) was measured using the latex agglutination technique. Patients were considered seropositive if any determination during the study was positive. The presence of antibodies against cyclic citrullinated peptide (anti-CCP) in serum was detected using the Diastat kit (Axis-Shield Diagnostics, Dundee, UK) with a cut-off value of $17 \mathrm{U} / \mathrm{mL}$.

Blood was obtained from fasting patients at a standardised time in the morning. The blood samples were centrifuged for 20 minutes at $2000 \mathrm{rpm}$. The serum were collected and kept at $-70^{\circ} \mathrm{C}$ until assayed. The measurement of Hcy levels was performed using an enzyme-linked immune sorbent assay (ELISA) kit (Axis homocysteine EIA, REF FH CY 100). Increased Hcy concentration was defined as plas$\mathrm{ma} \mathrm{Hcy} \mathrm{concentration} \mathrm{equal} \mathrm{to} \mathrm{or} \mathrm{greater} \mathrm{than} 11.20 \mu \mathrm{mol} / \mathrm{L}$. We compared the homocysteine levels between the RA and control group. We also analysed the correlation between levels of homocysteine and disease characteristics.

The disease activity of RA patients was calculated using a disease activity score comprising 28 joints (DAS 28) according to the method of Prevoo et al. (13). The DAS 28 consisted of 28 joint-swelling items and 28 joint-tender items, which included the proximal interphalangeal joint, metacarpal phalangeal joint, and the wrist, elbow, shoulder, and knee joints. The DAS 28 also included the erythrocyte sedimentation rate (ESR) and the visual analogue score (VAS). The VAS uses a horizontal 100-mm line, where patients indicate their degree of pain by placing a mark on a line between "no pain" (left end, $0 \mathrm{~mm}$ ) and "excruciating pain" (right end, $100 \mathrm{~mm}$ ). Values of DAS $28<3.2$ indicate low-disease activity, and values of DAS $28 \geq 3.2$ indicate moderate and high-disease activity. All patients completed Health Assessment Questionnaires (HAQ) for RA. At the time of this study, all patients were treated with one or two disease-modifying antirheumatic drugs (DMARD). Cyclooxygenase 2 (COX-2) inhibitors and nonsteroidal anti-inflammatory drugs (NSAIDs) were applied only occasionally. All 20 controls participated in this study and were matched by hospital personnel according to age sex (mean age 55.23 years \pm SD 4.232, min. 43, max. 60 years).

The following exclusion criteria were used for both groups: smoking (past 5 years), alcohol intake (past 12 months), use of narcotic drugs (never), hypertension, diabetes mellitus, chronic renal diseases, deficiency of folic acid, vitamin B6, vitamin B12, and any other form of arthritis except RA. All of the patients were informed about the aims of the study and written consents were obtained from them. The local institutional ethics committee approved the study protocol.

\section{Statistics}

The statistical analysis was performed using SPSS 15.0 for Windows. The data were presented as the mean \pm standard deviation (SD) and analysed using SPSS software version 10. A P $<0.05$ was considered statistically significant. The results 
Table 1. Baseline demographics and clinical characteristics of the RA patients and controls

\begin{tabular}{|c|c|c|c|}
\hline & $\begin{array}{l}\text { RA patients }(n=60) \\
(\text { mean } \pm S D)\end{array}$ & $\begin{array}{l}\text { Controls }(\mathrm{n}=20) \\
(\text { mean } \pm \mathrm{SD})\end{array}$ & P value \\
\hline $\begin{array}{l}\text { Age in years } \\
\text { (range) }\end{array}$ & $\begin{array}{l}52.46 \pm 7.39 \\
37-60\end{array}$ & $\begin{array}{l}54.23 \pm 5.23 \\
40-60\end{array}$ & NS \\
\hline BMI $\left(\mathrm{kg} / \mathrm{m}^{2}\right)$ & $23.59 \pm 1.54$ & $23.30 \pm 1.09$ & NS \\
\hline Duration of disease (years) & $7.32 \pm 3.18$ & - & - \\
\hline Visual Analogue Scale (mm) & $59 \pm 10$ & - & - \\
\hline Number of swollen joints & $2 \pm 2$ & - & - \\
\hline Number of tender joints & $6 \pm 2$ & - & - \\
\hline Disease activity score (DAS 28) & $4.80 \pm 0.84$ & - & - \\
\hline $\begin{array}{l}\text { Health assessment questionnaire-disability index } \\
\text { score-HAQ }\end{array}$ & $1.37 \pm 0.28$ & - & - \\
\hline
\end{tabular}

RA rheumatoid arthritis, NS not statistically significant, BMI body mass index,

are expressed as the mean \pm standard error of the mean. Data distribution was checked using the Shapiro-Wilk test and depending on its results, the appropriate parametric or nonparametric test was used. The differences between the two groups were assessed using Student's T-test or the MannWhitney U test. However, the differences between the values of the means among more than two groups were assessed using the ANOVA or Kruskal-Wallis test. The correlation between various variables was found using bivariate correlation, i.e., Spearman's coefficient of correlation.

Table 2. Comparison of the status of inflammation parameters and homocysteine in rheumatoid arthritis patients and controls

\begin{tabular}{|l|l|l|l|}
\hline Parameter & RA patients & Controls & p-value \\
\hline ESR $(\mathrm{mm}, 1 \mathrm{~h})$ & $34.8 \pm 19.98$ & $10,93 \pm 6,26$ & $\mathrm{p}<0.01$ \\
\hline $\mathrm{CRP}(\mathrm{mg} / \mathrm{L})$ & $13.7 \pm 12.22$ & $4.49 \pm 2.00$ & $\mathrm{p}<0.01$ \\
\hline $\mathrm{Hcy}(\mu \mathrm{mol} / \mathrm{L})$ & $11.79 \pm 3.72$ & $8.90 \pm 1.38$ & $\mathrm{p}<0.01$ \\
\hline
\end{tabular}

Values are represented as the mean \pm SD, ESR-erythrocytes sedimentation rates, CRP- C-reactive protein, Hcy-homocysteine

Table 3. Correlation between the plasma concentrations of homocysteine and the studied factor in RA patients and healthy controls

\begin{tabular}{|l|l|l|}
\hline Parameter & $\begin{array}{l}\text { RA patients } \mathbf{n = 6 0} \\
\text { (r coefficient, } \mathbf{~})\end{array}$ & $\begin{array}{l}\text { Controls } \mathbf{n}=\mathbf{2 0} \\
\text { (r coefficient, p) }\end{array}$ \\
\hline Age & $0.211(0.105)$ & $0.129(0.50)$ \\
\hline BMI $\left(\mathrm{kg} / \mathrm{m}^{2}\right)$ & $-0.003(0.97)$ & $0.331(0.07)$ \\
\hline ESR $(\mathrm{mm}, 1 \mathrm{~h})$ & $0.173(0.186)$ & $0.254(0.17)$ \\
\hline CRP $(\mathrm{mg} / \mathrm{L})$ & $\mathbf{0 . 3 2 2 ( \mathbf { 0 . 0 1 2 } )}$ & $0.033(0.86)$ \\
\hline $\begin{array}{l}\text { Duration of disease } \\
\text { (years) }\end{array}$ & $-0.037(0.780)$ & - \\
\hline $\begin{array}{l}\text { Number of swollen } \\
\text { joints }\end{array}$ & $-0.122(0.353)$ & - \\
\hline $\begin{array}{l}\text { Number of tender } \\
\text { joints }\end{array}$ & $-0.039(0.353)$ & - \\
\hline HAQ & $0.213(0.102)$ & - \\
\hline
\end{tabular}

RA-rheumatoid arthritis, BMI-body mass index, ESR-erythrocytes sedimentation rates, CRP- C-reactive protein, HAQ-Health assessment questionnaire-disability index score

\section{RESULTS}

The demographic and clinical characteristics of patients with RA and healthy controls are summarized in Table 1. Sixty DMARD patients received methotrexate, and 24 received a combination of methotrexate and hydroxychloroquine phosphate. Additionally, $63 \%$ of the patients continuously received low-dose corticosteroids for at least 1 year (average dose $7.5 \mathrm{mg}$ ) (Table 1 ).

Plasma homocysteine levels in patients with RA were significantly higher than those in the control group $(\mathrm{p}<0.05)$. The increase in the levels of ESR and CRP in the RA patient group was found to be highly significant $(\mathrm{p}<0.01)$ (Table 2$)$.

Table 3 shows the correlation between the plasma Hcy and the studied factors in RA patients and controls. The plasma Hcy concentrations were significantly correlated with CRP ( $\mathrm{r}=0.322, \mathrm{p}=0.012)$ in RA patients. Our findings suggest that serum Hcy level has no significant correlation with the duration of RA, levels of ESR, scores from the HAQ, or number of swollen and painful joints.

A statistically significant increase in the levels of plasma homocysteine was also observed in the patients with more severe disease (DAS 28>5.1) compared with patients with low or moderate disease activity (DAS $28 \leq 5.1)(\mathrm{p}<0.05)$ (Figure 1).

\section{DISCUSSION}

In this study, we found that the serum Hcy levels in patients with RA were higher than the normal range and were significantly higher than the Hcy levels among participants in the control group. The results of our study confirm the findings of previous studies, which report an elevation or a significant increase in plasma Hcy concentration. Many studies have also shown that the level of Hcy is significantly elevated in patients with RA compared with the level of Hcy in healthy subjects (14- 16).

The current view is that systemic inflammation, which is specific to all chronic inflammatory rheumatic diseases (CIRD), accelerates atherogenesis (17). Immunologic and metabolic markers (anti-cyclic citrullinated peptide (CCP) 


\section{6}

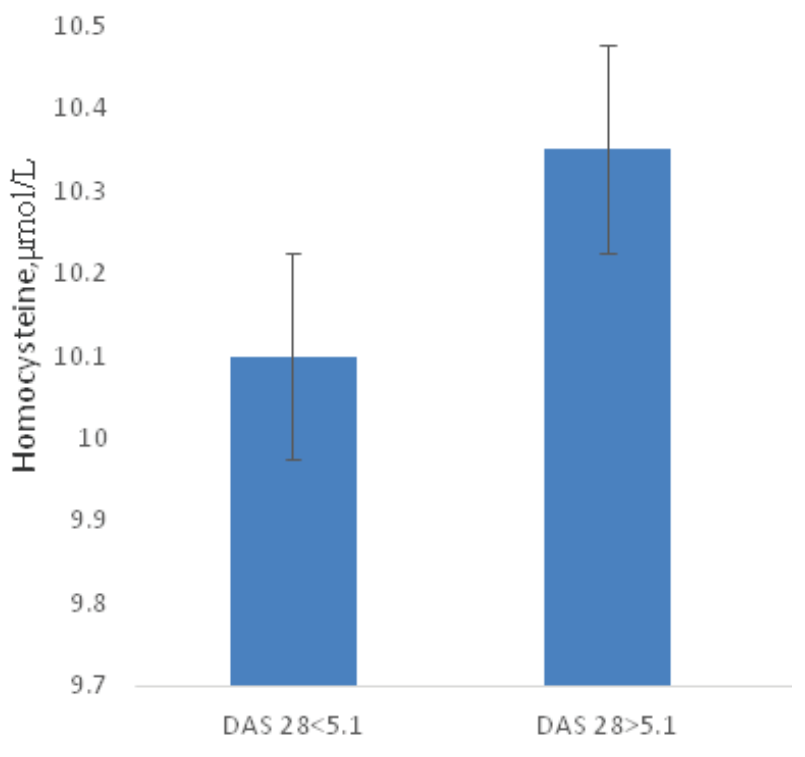

Figure 1. Comparasion of homocysteine and disease activity in rheumatoid arthritis patients

antibodies, IgM rheumatoid factor, proinflammatory cytokines and homocysteine) may play a role in the development of atherosclerotic disease in people with RA (17). This hypothesis is supported by the high cardiovascular (CV) morbidity and mortality rates and the high prevalence of all atherosclerosis stages and complications among RA patients (1).

A comprehensive evaluation and follow-up of both traditional and nontraditional CV risk factors, as well as the correct classification of risk reduction categories, are necessary in the study of RA (18). Our study shows that the values of CRP were significantly higher among RA patients than among participants in the control group. Continuous exposure to high grade systemic inflammation may be linked to accelerated atherosclerosis. Persistently elevated CRP values during the course of RA increase the risk of death due to cardiovascular disease (19). The CRP value determined using high-sensitivity assays appears to be an independent and robust prognostic factor for cardiovascular events. CRP is not only an indicator for generalized inflammatory reaction but is also a mediator involved in the pathogenesis of atherosclerosis. Increased levels of CRP have been found to correlate with the degree of subclinical atherosclerosis, measured by carotid artery intima-media wall thickness and the presence of clinically evident cardiovascular disease in adults with rheumatoid arthritis $(20,21)$.

The aim of this investigation was to evaluate the relationship between the duration of RA and the high activity of the inflammatory process in patients with RA (high levels of C-reactive protein, the disease activity scores, scores from the HAQ, and the number of swollen and painful joints) and hyperhomocysteinaemia. We showed a statistically significant correlation between homocysteine levels and CRP in patients with RA. Additionally, the plasma homocysteine levels were increased, and the levels of general inflammatory markers were elevated. Therefore, we conclude that homocysteine might affect the inflammatory status of patients and could be a predictive factor of hyperhomocysteinaemia in patients with RA. Regarding genetic influence, it is known that a genetic polymorphismmethylene-tetrahydrofolate reductase (MTHFR) associated with changes in the levels of homocysteine was also found to influence the development of endothelial dysfunction and the increased risk of cardiovascular disease in adults with RA (22). Based on a review, Salhab (4) concluded that there is a significant association between the subclinical atherosclerotic process and Hcy, and it shows potential as a cheap marker for risk stratification among asymptomatic patients. The results of these studies suggest the inclusion of plasma Hcy levels in future risk reduction protocols for identification of individuals at higher risk of atherosclerotic events to categorize them for more aggressive treatment with established preventive and therapeutic measures (4).

In our study, we found a correlation between plasma Hcy levels and disease activity in patients with RA. A statistically significant increase in the levels of plasma homocysteine was also observed in the patients with more severe disease when compared with those patients with low or moderate diseases activity. Recent studies have shown that RA radiological class, as an indicator of disease activity and progression, was a strong independent predictor of Hcy levels (23). In other studies, researchers found a positive correlation between homocysteine concentrations and the HAQ disability index (24). A previous study in RA patients found no association between the increase in Hcy concentration and the improvement in DAS (25) scores. A recent study has shown that myocardial ischaemia in patients with RA was associated with a high activity of the inflammatory process (high $\mathrm{C}$-reactive protein levels, disease activity score, score on the HAQ disability index, and number of swollen and painful joints) and hyperhomocysteinaemia (26).

The assessment and diagnosis of traditional and nontraditional CV risk factors followed by aggressive prevention and therapy, are necessary to achieve efficient control over the inflammation, immunologic and metabolic disorders specific to RA. This finding might indicate that Hcy has a stronger role as a marker of atherosclerotic disease than as a risk factor for atherosclerotic disease. Timely identification of patients with risk factors, particularly with new risk factors, enables adequate prevention of and treatment for CVD in rheumatoid arthritis patients.

\section{Acknowledgements}

This work is supported by Grant No 175043 from the Ministry of Science and Technical Development of the Republic of Serbia and Junior Project N ${ }^{\circ} 01 / 2014$ from the Faculty of Medical Sciences, University of Kragujevac, Serbia. 


\section{REFERENCES}

1. Peters MJ, Symmons DP, McCarey D, Dijkmans BA, Nicola $P$ et al. EULAR evidence-based recommendations for cardiovascular risk management in patients with rheumatoid arthritis and other forms of inflammatory arthritis. Ann Rheum Dis. 2010; 69(2): 312-325.

2. Martin-Martinez MA, Gonzalez-Juanatey C, Castaneda S, Llorca J, et al. Recommendations for the management of cardiovascular risk in patients with rheumatoid arthritis: scientific evidence and expert opinion. Semin Arthritis Rheum. 2014; 44(1): 1-8.

3. Borman P, Taşbaş O, Karabulut H, Tukun A, Yorgancioğlu R. Thymidylate synthase genetic polymorphism and plasma total homocysteine level in a group of Turkish patients with rheumatoid arthritis: relationship with disease activity and methotrexate toxicity. Rev Bras Reumatol. 2015. pii: S04825004(15)00017-0. doi: 10.1016/j.rbr.2014.12.001.

4. Selhub J. The many facets of hyperhomocysteinemia: studies from the Framingham cohorts. J Nutr. 2006; 136(6): 1726-1730.

5. Sarwar AB, Sarwar A, Rosen BD, Nasir K. Measuring subclinical atherosclerosis: is homocysteine relevant? Clin Chem Lab Med. 2007; 45(12): 1667-1677.

6. Baskan BM, Sivas F, Aktekin LA, Dogan YP, Ozoran K, Bodur H. Serum homocysteine level in patients with ankylosing spondylitis. Rheumatol Int. 2009; 29(12): 1435-1439.

7. Choi ST, Kim JS, Song JS. Elevated serum homocysteine levels were not correlated with serum uric acid levels, but with decreased renal function in gouty patients. Korean Med Sci. 2014; 29(6): 788-792.

8. Caramaschi P, Martinelli N, Biasi D, Carletto A, Faccini G, Volpe A, et al. Homocysteine plasma concentration is related to severity of lung impairment in scleroderma. J Rheumatol. 2003; 30(2): 298-304.

9. Perna M1, Roman MJ, Alpert DR, Crow MK et al. Relationship of asymmetric dimethylarginine andhomocysteine to vascular aging in systemic lupus erythematosus patients. Arthritis Rheum. 2010; 62(6): 1718-1722.

10. Jednacz E, Rutkowska-Sak L. Atherosclerosis in juvenile idiopathic arthritis. Mediators Inflamm. 2012; 2012: 714732.

11. Slot O. Homocysteine, a marker of cardiovascular disease risk, is markedly elevated in patients with gout. Ann Rheum Dis. 2013; 72(3): 457.

12. Aletaha D, Neogi T, SIlman A, Funovits J, Felson DT et al. 2010 rheumatoid arthritis classification criteria: an America college of rhuematology/European League against Rheumatism collaborative initiative. Ann Rheum Dis. 2010; 69: 1580-1588.

13. Prevoo ML, van't Hof MA, Kuper HH et al. Modified disease activity scores that include twenty-eight-joint counts. Development and validation in a prospective longitudinal study of patients with rheumatoid arthritis. Arthritis Rheum. 1995; 38: 44-48.
14. Van Ede AE, Laan RF, Blom HJ et al. Homocysteine and folate status in methotrexate-treated patients with rheumatoid arthritis. Rheumatology. 2002; 41(6): 658-665.

15. Kayacelebi AA, Willers J, Pham VV et al. Plasma homoarginine, arginine, asymmetric dimethylarginine and total homocysteine interrelationships in rheumatoid arthritis, coronary artery disease and peripheral artery occlusion disease. Amino Acids. 2015 Jan 25. [Epub ahead of print].

16. Willers J, Hahn A. Cardiovascular risk in patients with risk parameters and a German risk score model. Rheumatol Int. 2012; 32(12): 3741-3749.

17. Rezuș E, Floria M, Grigoriu A, Tamba BI, Rezus C.Cardiovascular Risk Factors In Chronic Inflammatory Rheumatic Diseases: Modern Assessment And Diagnosis. Curr Vasc Pharmacol. 2015 Jan 4. [Epub ahead of print].

18. Szekanecz Z, Kerekes G, Der H, Sandor Z et al. Accelerated atherosclerosis in rheumatoid arthritis. Ann N Y Acad Sci. 2007; 1108: 349-358. 19. Goodson NJ, Symmons DP, Scott DG, Bunn D, Lunt M, Silman AJ. Baseline levels of $\mathrm{C}$-reactive protein and prediction of death from cardiovascular disease in patients with inflammatory polyarthritis: a ten-year followup study of a primary care-based inception cohort. Arthritis and Rheumatism. 2005; 52(8): 2293-2299.

20. Gonzalez-Gay MA, Gonzalez-Juanatey C, Pineiro A, Garcia-Porrua C, Testa A, Llorca J. High-grade Creactive protein elevation correlates with accelerated atherogenesis in patients with rheumatoid arthritis. J Rheumatology. 2005; 32(7): 1219-1223.

21. Gonzalez-Gay MA, Gonzalez-Juanatey C, Lopez-Diaz MJ, et al. HLA-DRB1 and persistent chronic inflammation contribute to cardiovascular events and cardiovascular mortality in patients with rheumatoid arthritis. Arthritis Rheum. 2007; 57(1): 125-132.

22. Palomino-Morales R, Gonzalez-Juanatey C, VazquezRodriguez TR, et al. A1298C polymorphism in the MTHFR gene predisposes to cardiovascular risk in rheumatoid arthritis. Arthritis Res Ther. 2010; 12(2): R71.

23. Nowakowska-Plaza A, Potaczek DP, Gluszko P, UndasA. Antibodies to N-homocysteinylated albumin and haemoglobin in patients with rheumatoid arthritis: a 2014; 43(1): 17-21.

24. Woolf K, Manore MM. Elevated plasma homocysteine and low vitamin B-6 status in nonsupplementing older women with rheumatoid arthritis. J Am Diet Assoc. 2008; 108(3): 443-453.

25. van Ede AE, Laan RF, Blom HJ, Boers GH et al. Homocysteine and folate status in methotrexate-treated patients with rheumatoid arthritis. Rheumatology. 2002; 41(6): 658-665.

26. GaliutinaOIu, BychakOV.Relationship of silent myocardial ischiemia with the course of rheumatoid arthritis and hyperhomocysteinemia. Lik Sprava. 2011; (1-2): 48-52. 